Daniel C. Najork

Reading the Old Norse-Icelandic Maríu saga in Its Manuscript Contexts 


\section{The Northern Medieval World}

On the Margins of Europe

\section{Editorial Board}

Carolyne Larrington, St. John's College, Oxford (Chair)

Oren Falk, Cornell University

Dawn Hadley, University of York

Kate Heslop, University of California, Berkeley

Jana Schulman, Western Michigan University

Jón Viðar Sigurðsson, Universitetet i Oslo 
Daniel C. Najork

Reading the Old

Norse-Icelandic Maríu

saga in Its Manuscript Contexts

DE GRUYTER MEDIEVAL 
ISBN 978-1-5015-1853-9

e-ISBN (PDF) 978-1-5015-1414-2

e-ISBN (EPUB) 978-1-5015-1412-8

\section{Library of Congress Control Number: 2020948127}

Bibliographic information published by the Deutsche Nationalbibliothek

The Deutsche Nationalbibliothek lists this publication in the Deutsche Nationalbibliografie; detailed bibliographic data are available on the internet at http://dnb.dnb.de.

(C) 2021 Walter de Gruyter GmbH, Berlin/Boston

Cover image: Copenhagen, Arnamagnæan Collection, AM 232 fol, 55r. Photograph: Suzanne Reitz. Published with permission from the Arnamagnæan Institute

Typesetting: Integra Software Services Pvt. Ltd.

Printing and binding: CPI books $\mathrm{GmbH}$, Leck

www.degruyter.com 


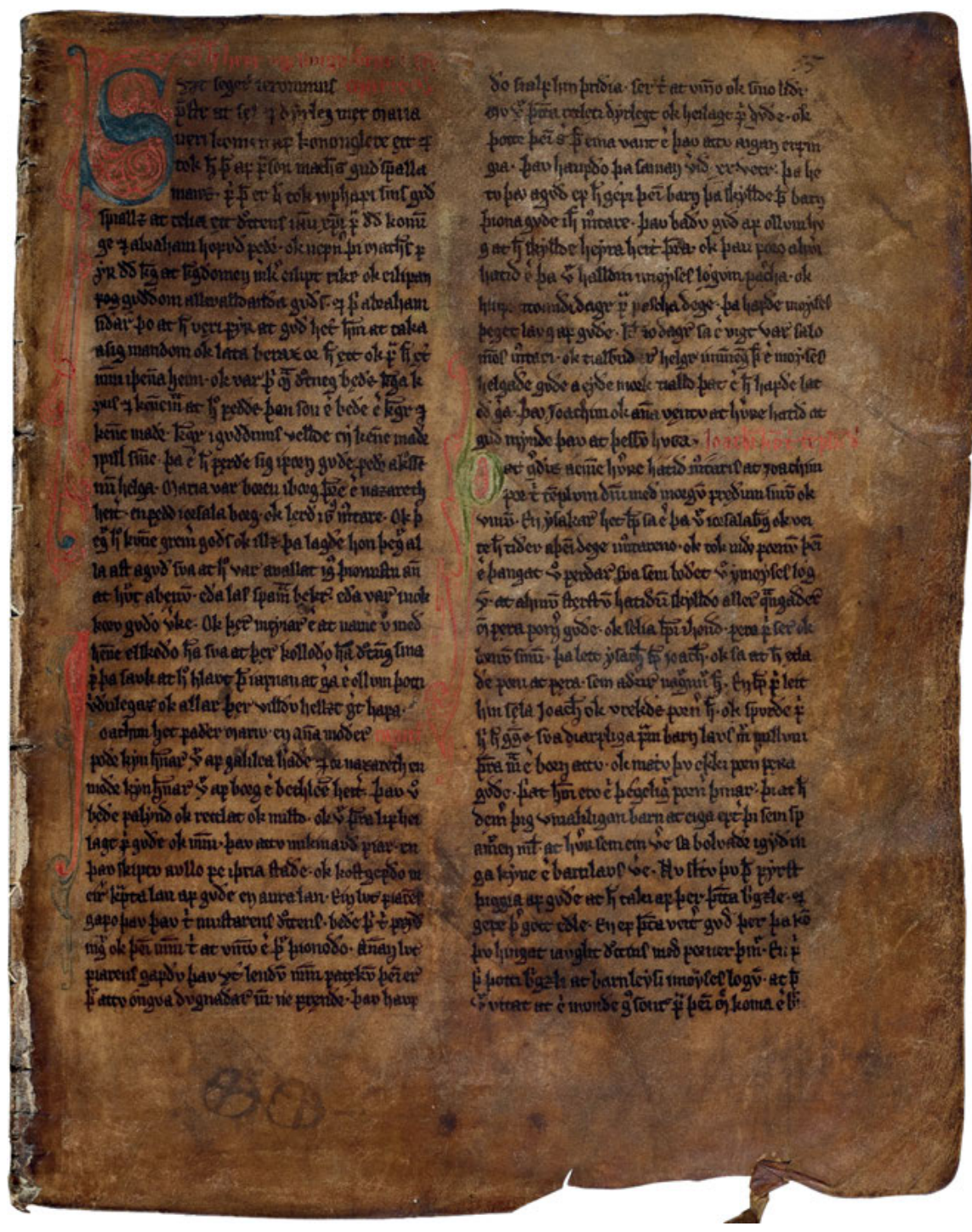

Copenhagen, Arnamagnæan Collection, AM 232 fol. 55r. Photograph: Suzanne Reitz. Published with permission from the Arnamagnæan Institute. 

Dedicated to the memory of my brother, Jeffrey C. Najork

November 17, 1975 - December 23, 2017 
